\title{
Low-grade magnesium oxide by-products for environmental solutions: Characterization and geochemical performance
}

\author{
R. del Valle-Zermeño a,*, J. Giro-Paloma a, J. Formosa a,b, J.M. Chimenos a \\ ${ }^{a}$ Departament de Ciència de Materials i Enginyeria Metallúrgica, Universitat de Barcelona, Martí i Franquès, 1, E-08028 Barcelona, Spain \\ ${ }^{\mathrm{b}}$ Departament de Construccions Arquitectòniques II, Universitat Politècnica de Catalunya, Barcelona, Spain
}

\section{a r t ic le in fo}

\section{Article history:}

Received 6 June 2014

Accepted 16 February 2015

Available online xxxx

Keywords:

Acid neutralization capacity

Metal leaching

By-product

Geochemical predictions a bstract

The reutilization of the by-products from the calcination of natural magnesite for environmental solutions is conditioned by the availability of $\mathrm{MgO}, \mathrm{CaO}$ and other compounds. In order to overcome their great heterogeneity, an exhaustive chemical and physical characterization is necessary in order to assess their potential applications. In this study, the acid neutralization capacity (ANC) test was used to categorize three types of byproducts (LG-MgO, LG-D and LG-F), which mainly differed according to source ore and processing conditions.

The experimental data concerning the leaching of $\mathrm{Mg}^{2+}, \mathrm{Ca}^{2+}, \mathrm{Fe}^{2+}$ and $\mathrm{SO}^{2-}$ was corroborated with geochemical predictions using the modelling software Visual MINTEQ. Likewise, the main solubility-controlling mineral phases were also identified. According to the results, there is a buffer capacity within the $\mathrm{pH}$ 8-10 range, mainly dominated by the neutralization of $\mathrm{MgO} / \mathrm{Mg}(\mathrm{OH})_{2}$, equilibrium with a small contribution from the carbonate content at lower $\mathrm{pH}$ values. The release of sulphates showed a non-pH dependency attributed to the solubility of $\mathrm{CaSO}_{4}$ and elemental sulphur present in petcoke. For dust materials, leaching of $\mathrm{Fe}$ was minimal above $\mathrm{pH} 6$ owing to the insoluble nature of the $\mathrm{Fe}_{2} \mathrm{O}_{3} / \mathrm{Fe}_{3} \mathrm{O}_{4}$ pair. Accordingly, the by-products labeled as LG-D and LG-F are better suited for stabilizing solid wastes or wastewater that are acid while LG-MgO is more appropriate for alkaline residues such as contaminated soils. In both cases, a suitable $\mathrm{pH}$ range in which $\mathrm{pH}$-dependent heavy metals and metalloids show minimum solubility can be obtained. The use of these by-products guarantees an environmentally friendly alkali reservoir for the long-term stabilization of heavy metals and metalloids at a very competitive price as a substitute for the widely used lime.

\section{Introduction}

Magnesium oxide $(\mathrm{MgO})$ is one of the most important raw materials used in the refractory industry (Salomão et al., 2007). It is predominantly produced by the calcination of natural magnesite $\left(\mathrm{MgCO}_{3}\right)$ (Birchal et al., 2000; Demir et al., 2003; Zhu et al., 2013). During this thermal process, several by-products rich in magnesium are generated. In order to promote environmental sustainability and enhance the exploitation of these by-products, the three R's strategy (Reduce, Reuse and Recycle) should be promoted as an integral part of every industrial philosophy. The need to recover resources is not only related to benefits to the environment but also to the maintenance of natural resources. In this regard, the reuse of industrial by-products in environmental solutions by replacing other industrial products not only addresses issues of sustainability but also of greater environmental benefits.

After extraction from ore, the natural mineral is taken to classifiers and collectors for sieving, and the selected minerals are fed to the kiln

- Corresponding author. Tel.: +34 934021 316; fax: +34 934035438. E-mail address: rdelvallez@ub.edu (R. del Valle-Zermeño). for calcination. Both the temperature of calcination and the time of residence are important for conditioning the quality of the $\mathrm{MgO}$ and thus its potential applications (Zhu et al., 2013). The so-called caustic magnesia is obtained at low temperature ranges $\left(1200^{\circ} \mathrm{C}\right)$ and shows high reactivity, while the dead-burnt magnesia is obtained at temperature ranges close to $1600{ }^{\circ} \mathrm{C}$, and is less reactive than caustic magnesia because of the effect of sinterization on its crystalline structure. Regardless of the calcination conditions, the combustion gases generated at the outlet of the kiln are taken into the air pollution control system, consisting of fabric filters and cyclones, where a large proportion of the solid particles and flue-dust is retained. These components combine to form cyclone dust (CD), which is considered the bulkiest by-product obtained at the end of the calcination process. It is characterized for being a mixture of magnesium and calcium oxides as well as different proportions of dolomite, siliceous materials and other impurities that affect its alkaline behaviour and reutilization potential. CD is more widely known as Low-Grade $\mathrm{MgO}$ (LG-MgO). Its great heterogeneity complicates the post-treatment and without any reclamation, it is stored in the open. After 6-8 months, the natural spontaneous process of weathering hydrates LG-MgO to Low-Grade $\mathrm{Mg}(\mathrm{OH})_{2}$ $\left(\mathrm{LG}-\mathrm{Mg}(\mathrm{OH})_{2}\right)$. 
The reutilization of by-products from the calcination of natural magnesite is mainly conditioned by the availability of $\mathrm{MgO}, \mathrm{CaO}$, and other compounds. The main differences among these by-products are chiefly a function of both the raw materials and the thermal processes involved in their production, which condition their chemical and physical characteristics.

\subsection{Reutilization routes of $\mathrm{MgO}$ by-products}

With the aim of ensuring sustainable and beneficial use, previous studies carried out by our research group have highlighted the potential for reutilization of these low-grade magnesium (hydr)oxides in many applications despite their great heterogeneity. Fernández et al. (1999) described a method to obtain basic magnesium carbonates by means of the carbonation of LG-MgO slurries with the aim of using them as an additive for pigments and papermaking or as a flame retardant in polymers. In the same way, the use of $\mathrm{LG}-\mathrm{Mg}(\mathrm{OH})_{2}$ has been tested with very promising results as a flame retardant filler in polymers and as aggregates in the formulation of fire-protecting mortars (Fernández et al., 2009; Formosa et al.,2011).

In the environmental field, it is known that the leaching of heavy metals and some metalloids is strongly dependent on $\mathrm{pH}$ (Van Herreweghe et al., 2002). In this context, $\mathrm{MgO}$ acts as a buffering agent within the $\mathrm{pH}$ 9-11 range, minimizing heavy metal solubility and avoiding the re-dissolution that occurs when using only lime (García et al., 2004). In this context, and more precisely in landfill management, the use of different types of dolomitic limes with varying amounts of $\mathrm{MgO}$ equivalents has proved to be effective in the stabilization of electric arc furnace (EAF) dust as an alternative to the use of lime

and/or ordinary Portland cement (Cubukcuoglu and Ouki, 2012; Fernández et al., 2003). In this regard, remediation of heavy metal contaminated soils is currently an important worldwide issue that is of great concern to many communities and municipalities (García et al., 2004; Peng et al., 2009; Yao et al., 2012). The use of magnesium (hydr)oxide by-products guarantees an alkali reservoir for the longterm stabilization of heavy metals and metalloids at a very competitive price. García et al. (2004) reported that contaminated soil stabilized

with LG-MgO shows, independently of the quantity of stabilizer employed, a pH close to 9.2. Moreover, a reduction greater than $80 \%$ of the metals and metalloids released is feasible when applying this byproduct. Another study carried out by the authors focused on the potential leaching of toxic trace elements from $\mathrm{MgO}$ by-products during their reutilization: even at very acidic conditions, the majority of toxic species (As, $\mathrm{Pb}, \mathrm{Zn}, \mathrm{Cr}, \mathrm{Cu}, \mathrm{Ti}, \mathrm{Mn}, \mathrm{Co}$ and $\mathrm{Ni}$ ) hardly dissolve and their concentration values remained under regulatory limits (Chimenos et al., 2012).

The buffering $\mathrm{pH}$ range is controlled by the solubility of the magnesium hydroxide. In this respect, an alternative to the natural spontaneous process for obtaining $\mathrm{LG}-\mathrm{Mg}(\mathrm{OH})_{2}$ was assessed by the authors using different hydration agents (del Valle-Zermeño et al., 2012). The results reported by the authors showed that much shorter hydration times are possible and therefore, an industrial alternative to the spontaneous process could satisfy an increasing demand for magnesium hydroxide.

Low-grade magnesium (hydr)oxides have also been found to be suitable and economically feasible for use in remediation and/or wastewater treatment. Thereby, permeable reactive barriers using $\mathrm{MgO}$ as a filler were tested for removing heavy metals from contaminated ground (Cortina et al., 2003; Navarro et al., 2006; Rötting et al., 2006). Moreover, magnesium oxide as a source of magnesium has been used as a reagent to remove and recover ammonium and/or phosphates from wastewater; these precipitate in the form of struvite $\left(\mathrm{MgNH}_{4} \mathrm{PO}_{4} \cdot 6 \mathrm{H}_{2} \mathrm{O}\right)$, bobierrite $\left(\mathrm{Mg}_{3}\left(\mathrm{PO}_{4}\right)_{2} \cdot 8 \mathrm{H}_{2} \mathrm{O}\right)$ or newberyite $\left(\mathrm{MgHPO}_{4} \cdot 3 \mathrm{H}_{2} \mathrm{O}\right)$ in the presence of magnesium (Chimenos et al., 2003, 2006). On the other hand, chemically bonded phosphate ceramics (CBPCs) are well suited for hazardous waste encapsulation because solidification occurs at low temperatures and within a wide $\mathrm{pH}$ range
(Rao et al., 2000). CBPCs are mainly fabricated from an acid-base reaction between calcined $\mathrm{MgO}$ and monopotassium phosphate $\left(\mathrm{KH}_{2} \mathrm{PO}_{4}\right)$ in solution to form a hard and dense magnesium potassium phosphate hydrate $\left(\mathrm{MgKPO}_{4} \cdot 6 \mathrm{H}_{2} \mathrm{O}\right)$ ceramic. The use of a highly pure $\mathrm{MgO}$ requires prior calcination at $1300{ }^{\circ} \mathrm{C}$ (Jeong and Wagh, 2003). This significantly increases the cost of the raw materials, complicating its potential use as a substitute for ordinary Portland cement for encapsulation. However, the use of $\mathrm{MgO}$-containing by-products as raw materials for CBPC formulation could reduce production costs while improving mechanical properties (Formosa et al., 2012).

\subsection{Reuse of MgO by-products as stabilizing agents}

The effectiveness of LG-MgO as a stabilizing agent in heavily polluted soils or as a reagent in wastewater treatment, as well as other potential environmental applications, is a function of its reactivity and, mainly, its behaviour across the whole $\mathrm{pH}$ range (Ho et al., 2012). The reactivity of $\mathrm{MgO}$ is usually measured using the citric acid test, in which the time needed for the magnesium sample to neutralize the citric acid solution is measured (Strydom et al., 2005). It is also directly related to its specific surface area and particle size distribution (Demir et al., 2006). The acid-base properties of solid wastes have been found to considerably influence the leaching of solid wastes by changing the $\mathrm{pH}$ environment (González-Núñez et al., 2012; Yan et al., 2000). The pH environment of the system can be defined by the buffering capacity, which is usually measured by means of the acid neutralization capacity (ANC) test (CEN 14997). This standardized test determines the ability of any material to maintain a stable $\mathrm{pH}$ range as acid is added. The ANC test is a measure of the acidity of a solution and it is almost linearly related to alkalinity and non-linearly related to $\mathrm{pH}$ (Förstner and Haase, 1998; Neal et al., 1999).

Against the above background, the main objective of this study was to characterize the main by-products obtained from the calcination of natural magnesite in order to determine the boundaries of reutilization in the environmental field taking into consideration the materials' heterogeneity. For this purpose, their chemical and mineralogical composition as well as various physical properties were characterized. Likewise, the ANC test was used as a tool to predict their effectiveness as neutralization agents in acid effluents and their buffering capacity in, for example, the amendment of highly contaminated soils or the stabilization of solid wastes, as this can give sufficient information about the release of metals in certain $\mathrm{pH}$ conditions. Moreover, this capacity factor is significant for predicting the potentially reactive amount of waste in neutralizing reactions (Cappuyns et al., 2004; Yan et al., 2000). The experimental results were further compared to geochemical modelling predictions using Visual MINTEQ, which is based on the code originally built for MINTEQA2 (Allison and Brown, 1991). This geochemical modelling software allows the assessment of the transport and precipitation of heavy metals as well as adsorption equilibriums (Shi et al., 2013; Wagner and Kaupenjohann, 2014; Yu et al., 2014). It is also used for leaching predictions and for calculating the composition of the leachates in equilibrium with potential solubility-controlling minerals (Houben et al., 2012; Jung et al., 2012; Meima and Comans, 1997, 1999; Sjöstedt et al., 2013). Thus the mineral phases controlling

the leaching in the $\mathrm{pH}$ range of interest for each by-product were identified by comparing theoretical modelling with experimental data.

The use of these by-products addresses two issues: on one hand, it becomes possible to reuse a by-product that follows the path towards sustainability and on the other hand, an environmental solution is attained by means of an environmentally friendly agent.

\section{Materials and methods}

Three by-products were considered, differing mainly in their particle size and $\mathrm{Mg} / \mathrm{Ca}$ content. Selected samples of around $25 \mathrm{~kg}$ each were supplied by Magnesitas Navarras S.A., located in Navarra (Spain). 
Their origins can be described as follows. Once the ore is extracted from the natural deposits and beneficiated to increase the content of magnesite by reducing the occurrence of calcite and dolomite, it is fed into two rotary kilns at $1200^{\circ} \mathrm{C}$ and $1600{ }^{\circ} \mathrm{C}$ for calcination, to obtain caustic and sintered magnesia, respectively. The gases generated from these two kilns are taken into an air pollution control system where fly particles are collected in fabric filters. The collected dust material is classified as LG-MgO and was the first by-product under consideration. The second by-product was from other natural ores enriched in dolomite - $\mathrm{CaMg}\left(\mathrm{CO}_{3}\right)_{2}$ - the corresponding dust material being catalogued as Low-Grade Dolomite (LG-D). The third by-product was the finest fraction (smaller than $500 \mu \mathrm{m}$ ) of the caustic calcined magnesite (LG-F) collected at the outlet of the kiln after sieving. For chemical and physical characterization, a representative subsample (about $5 \mathrm{~kg}$ ) of each by-product was obtained by quartering each of the initial samples to a $1 / 16$ split.

Nitric acid (65\%) and citric acid were provided by Scharlau Chemie S.A. (Spain). Deionized water with conductivity lower than $5 \mu \mathrm{S} ı \mathrm{~cm}^{-1}$ was used in all tests.

\subsection{Physical and chemical characterization}

The representative subsamples were analysed by X-Ray fluorescence (XRF) using a Philips PW2400 X-ray sequential spectrophotometer to elucidate major and minor elements. Moreover, the crystalline phases were determined by X-Ray Diffraction (XRD) in a BraggBrentano Siemens D-500 powder diffractometer with $\mathrm{CuKa}$ radiation. Physical properties were described by means of the Particle Size Distribution (PSD) using a Beckman Coulter LS 13320 laser analyser, and the specific surface by the BET single point method using a Micrometrics Tristar 3000 porosimeter. A Zwek Optical Microscope was used for imaging. A TA Instruments SDT Q600 Simultaneous TG-DSC was used to perform the Thermogravimetic Analyses (TA) from $50{ }^{\circ} \mathrm{C}$ to $1000^{\circ} \mathrm{C}$ at $10^{\circ} \mathrm{C} \cdot \mathrm{min}^{-1}$ in an inert atmosphere.

\subsection{Citric acid test}

This test was performed in order to evaluate $\mathrm{MgO}$ reactivity. The citric acid activity test was designed to determine the reactivity of $\mathrm{MgO}$ by acid neutralization using phenolphthalein as an indicator. The magnesia activity time is the time elapsed between the addition of acid and the formation of a reddish colour (Shand, 2006). Acid neutralization values of less than $60 \mathrm{~s}$ are used to define highly reactive (softburnt) $\mathrm{MgO}$. Medium reactive $\mathrm{MgO}$ gives a measure between 180 and $300 \mathrm{~s}$, while a low reactivity $\mathrm{MgO}$ (hard-burnt) and a dead-burnt $\mathrm{MgO}$ give values greater than $600 \mathrm{~s}$ and $900 \mathrm{~s}$ respectively (Strydom et al., 2005).

\subsection{Acid neutralization capacity}

As previously mentioned, the ANC test (CEN 14997) allows determination of the buffering capacity to maintain a stable $\mathrm{pH}$ range as acid is added. The protocol can be divided into two parts. The first part is a preliminary stage in which the selected by-product is subjected to consecutive and ordered acid additions, in order to obtain a curve of $\mathrm{pH}$ versus hydronium $\left(\mathrm{H}_{3} \mathrm{O}^{+}\right)$per mass of solid. This phase began by placing representative samples and bringing them into contact with ten times the weight of water under continuous stirring for $24 \mathrm{~h}$. During this period, different volumes of $\mathrm{HNO}_{3}(65 \mathrm{wt} . \%)$ were added in order to gradually decrease $\mathrm{pH}$ to 4 . Any abrupt drop in $\mathrm{pH}$ can be overtaken by diluting the acid. The final values of $\mathrm{H}_{3} \mathrm{O}^{+}$per mass of solid added were calculated taking into account both the volume and the concentration of acid added during the whole experiment. Subsequently, the quantity of acid required to achieve a specific $\mathrm{pH}$ was estimated by extrapolating the necessary $\mathrm{H}_{3} \mathrm{O}^{+}$per mass of solid to reach the desired $\mathrm{pH}$ value (hereinafter referred to as the pre-established value).
The second part of the test was carried out by placing $30 \mathrm{~g}$ of solid in contact with $0.3 \mathrm{~L}$ of deionized water under continuous stirring. After $15 \mathrm{~min}$, the natural $\mathrm{pH}$ of the solid was measured and the quantity of acid required to reach the pre-established value was added afterwards. The $\mathrm{pH}$ was measured at specific times: $0.25,4,44$ and $48 \mathrm{~h}$. The period between 44 and $48 \mathrm{~h}$ was used to adjust the required $\mathrm{pH}$ by adding more acid. After $48 \mathrm{~h}$ the corresponding eluates were passed through $0.45 \mu \mathrm{m}$ polypropylene membrane filters, acidified by adding a few drops of $\mathrm{HNO}_{3}$ and preserved in a fridge at $4{ }^{\circ} \mathrm{C}$ for subsequent analysis of the concentration of selected metals and sulphates. The correct execution of the second part of the test entailed several restrictions that can be summarized as follows: i) the liquid-to-solid (L/S) ratio must never exceed 11 at the end of the experiment; ii) the supplementary acid additions between 44 and $48 \mathrm{~h}$ must be taken into account for the aforementioned final L/S; and iii) deviation with respect to the preestablished value must be kept under $0.3 \mathrm{pH}$ units. The concentration of metals was determined by inductively coupled argon plasma optic spectrometry (ICP-OES), and that of sulphates by spectrophotometry.

\subsection{Geochemical modelling and leaching predictions}

In order to compare leaching experimental data from the ANC test with geochemical modelling predictions, the Visual MINTEQ software (v. 3.0/3.1) was used. Unlike other studies, in which the total concentration of inorganic elements measured in the leachates is the main input information (Meima and Comans, 1997, 1999; Meima et al., 1999; Merrikhpour and Jalali, 2013; Ohno et al., 2014; Shi et al., 2013; Wagner and Kaupenjohann, 2014; Yu et al., 2014), the chemical characterization of the mineral phases in each by-product was used for modelling as follows: (i) input files were the total concentration of each known mineral phase (whenever possible) for each by-product as a finite solid phase in a multi-problem model by sweeping $\mathrm{pH}$ in the whole range of study; (ii) the theoretical concentration of the significant aqueous species was compared to experimental leaching data; and (iii) the potential solubility-controlling minerals were selected on the basis of the saturation indices that approached zero $(-1 \mathrm{~b}$ SI $b+1)$. Modelling predictions are presented together with experimental data for major species $\left(\mathrm{Ca}^{2+}, \mathrm{Mg}^{2+}, \mathrm{Fe}^{2+}\right.$ and $\left.\mathrm{SO}_{4-}\right)$ in a graph of log concentration versus $\mathrm{pH}$. The mineral phases that according to the software are most likely to control solubility are also presented in the graph. In order to improve the fit of experimental data with the theoretical predictions, the input files defined in (i) were modified by changing the mineral phase of a given element (e.g. Fe or $\mathrm{S}$ ) or by adding surface complexation reactions or adsorption isotherms.

\section{Results and discussion}

\subsection{By-product characterization}

The main chemical composition obtained by XRF analysis is shown in Table 1. As it can be seen, magnesium was the main element in the three by-products, with an average content of $68.1,41.5$ and $78.7 \mathrm{wt} . \%$ for LG-MgO, LG-D and LG-F, respectively. The calcium content was also important, especially in LG-D, with an average content of

Table 1

By-products chemical composition determined by XRF analysis.

\begin{tabular}{lccl}
\hline & LG-MgO (\%) & LG-D (\%) & LG-F (\%) \\
\hline $\mathrm{MgO}$ & 68.1 & 41.5 & 78.7 \\
$\mathrm{CaO}$ & 8.9 & 22.1 & 9.9 \\
$\mathrm{SO}_{3}$ & 8.1 & 8.3 & 2.1 \\
$\mathrm{Fe}_{2} \mathrm{O}_{3}$ & 2.6 & 3.5 & 2.9 \\
$\mathrm{SiO}_{2}$ & 1.5 & 0.7 & 2.8 \\
$\mathrm{~K}_{2} \mathrm{O}$ & 1.5 & 0.4 & - \\
$\mathrm{LOI}$ & 8.7 & 23.1 & 3.6 \\
\hline
\end{tabular}


$22.1 \mathrm{wt} . \%$. This was the expected value, owing to the natural ore of origin. Other impurities such as silica and iron were uniformly present in dust materials ( $\mathrm{LG}-\mathrm{MgO}$ and LG-F). It is also worth mentioning the average sulphur content of 8 wt.\% in both dust materials but significantly lower levels $(\sim 2 \mathrm{wt} . \%)$ in LG-F, the origin of which is mainly attributed to the petroleum coke used as fuel for calcination in the kilns, as previously reported by Formosa et al. (2011). Loss on ignition (LOI) differed substantially among the three by-products as a consequence of the duration ofcalcination. Dustmaterialshad spentless timeinsidethecalcination kiln and therefore a larger proportion of carbonates remained uncalcined.

The correspondingX-Ray Diffraction patterns are presented in Fig. 1. As it is shown, magnesium was mainly present as periclase (crystalline $\mathrm{MgO}$ ) in all by-products, although its presence as uncalcined dolomite was significant in LG-D and to a lesser extent in LG-MgO. The main forms of calcium occurrence in both dust materials were dolomite and anhydrite with small proportions of $\mathrm{CaCO}_{3}$. Calcium in LG-F was mainly present as $\mathrm{CaO}$. The phases of iron were not identified in the XRD patterns due to their low levels and hence its form of occurrence had to be predicted by geochemical modelling. This will be addressed in the next section.

With respect to physical properties (Table 2), LG-MgO and LG-D presented the largest specific surface (BET) and therefore greatest reactivity (Demir et al., 2006), with a largely irregular particle size distribution, as seen in the three images taken with an optical microscope (Fig.2).In this aspect, LG-MgO possessed the smallest particlesize, with a mean size of $23.1 \mu \mathrm{m}$. Not all the magnesium content can actively influence the ANC as some mineral phases remained inactive. In order to quantify all phases in each by-product the aforementioned results were used together with results from the thermal decomposition of the three raw by-products (Fig. 3). The mass loss steps can be ascribed to moisture and water of crystallization loss (below $\left.200{ }^{\circ} \mathrm{C}\right), \mathrm{Mg}(\mathrm{OH})_{2}$ decomposition to $\mathrm{MgO}$ (from 200 to $450{ }^{\circ} \mathrm{C}$ ), $\mathrm{MgCO}_{3}$ decomposition to $\mathrm{MgO}$ and $\mathrm{CO}_{2}$ (between 450 and $625^{\circ} \mathrm{C}$ ), $\mathrm{CaMg}\left(\mathrm{CO}_{3}\right)_{2}$ decomposition to $\mathrm{MgO}, \mathrm{CaO}$ and $\mathrm{CO}_{2}$ (between 625 and $750{ }^{\circ} \mathrm{C}$ ) and $\mathrm{CaCO}_{3}$ decomposition to $\mathrm{CaO}$ and $\mathrm{CO}_{2}$ (up to $1000^{\circ} \mathrm{C}$ ). The decomposition of $\mathrm{MgSO}_{4}$ and $\mathrm{CaSO}_{4}$ at around 1100 and $1200^{\circ} \mathrm{C}$, respectively, was only observed for LG-D (TA not shown). The mass loss percentages for each reaction of decomposition were used to fully characterize each by-product according to a previous study carried out by the authors (del ValleZermeño et al., 2012). These results are presented in Table 3. As shown, periclase was the main form of occurrence. The presence of $\mathrm{MgCO}_{3}$ and $\mathrm{CaCO}_{3}$ was also noted, particularly in $\mathrm{LG}-\mathrm{MgO}$, with the total calcium content present in the carbonate form. Dolomite -
Table 2

Particle size distribution (PSD) and specific surface (BET) of the three by-products. Note: $d_{X}$ denote the X percentage of particles with a size below the indicated.

\begin{tabular}{|c|c|c|c|}
\hline \multicolumn{4}{|l|}{$\operatorname{PSD}(\mu \mathrm{m})$} \\
\hline & LG-MgO & LG-D & $L G-F$ \\
\hline $\mathrm{d}_{10}$ & 2.0 & 2.9 & 15.4 \\
\hline$d_{25}$ & 6.2 & 10.1 & 55.2 \\
\hline$d_{50}$ & 16.6 & 28.2 & 125.3 \\
\hline$d_{75}$ & 32.6 & 55.0 & 205.1 \\
\hline$d_{96}$ & 65.5 & 107.9 & 339.0 \\
\hline Mean ${ }_{2-1}$ & 23.1 & 37.5 & 141.4 \\
\hline $\operatorname{BET}(\mathrm{m} \cdot \mathrm{g} \quad)$ & 4.6 & 6.6 & 2.6 \\
\hline
\end{tabular}

$\mathrm{CaMg}\left(\mathrm{CO}_{3}\right)_{2}$ - was the main form of occurrence in LG-D, whose ore of origin is enriched in this compound. The presence of $\mathrm{MgSO}_{4}$ and $\mathrm{CaSO}_{4}$ in this by-product was also notable. LG-F contained the highest amount of $\mathrm{MgO}(76.7 \%)$ and a $\mathrm{CaO}$ content similar to $\mathrm{LG}-\mathrm{MgO}$. The high levels of $\mathrm{MgO}$ can again be attributed to the long residence time inside the calcination kiln alongside the product itself, avoiding any mixing with combustion gases. Likewise, the time and temperature of the calcination process dramatically affect the reactivity of the $\mathrm{MgO}$ formed, where reactivity refers to hydration into $\mathrm{Mg}(\mathrm{OH})_{2}$ by exposure to water and moisture (Aphane et al., 2009; Strydom et al., 2005). In this context, Yan et al. (2000) reported that the hydration of mineral phases is important for neutralizing processes. Therefore, a relationship between reactivity, time of calcination and neutralizing capacity can be inferred for the three by-products.

As an initial approach the citric acid test was performed in order to evaluate the reactivity of the three by-products. The citric acid activity test showed neutralization times greater than $900 \mathrm{~s}$ for both LG-D and LG-F and times greater than $810 \mathrm{~s}$ for LG-MgO. According to these values, LG-D and LG-F should be termed "dead-burned" magnesia and LG-MgO as "hard-burnt" magnesia. It should be noted that this test was designed to categorize highly pure magnesia, and therefore the content of $\mathrm{CaO}$ in each by-product, as well as the presence of other alkalis, could also have influenced the neutralization of the added acid, resulting in even higher reactivity. Therefore, the reactivity of the magnesia would be expected to be even lower than that predicted by the citric acid test, as in the case of LG-MgO. This drawback can be overcome by measuring the ANC. This low reactivity allows the use of these highly rich magnesium oxide by-products without previous calcination, e.g. in the formulation of CBPC, where the fast acid-base reaction should be controlled in order to obtain acementitious material (Formosa et al., 2012).

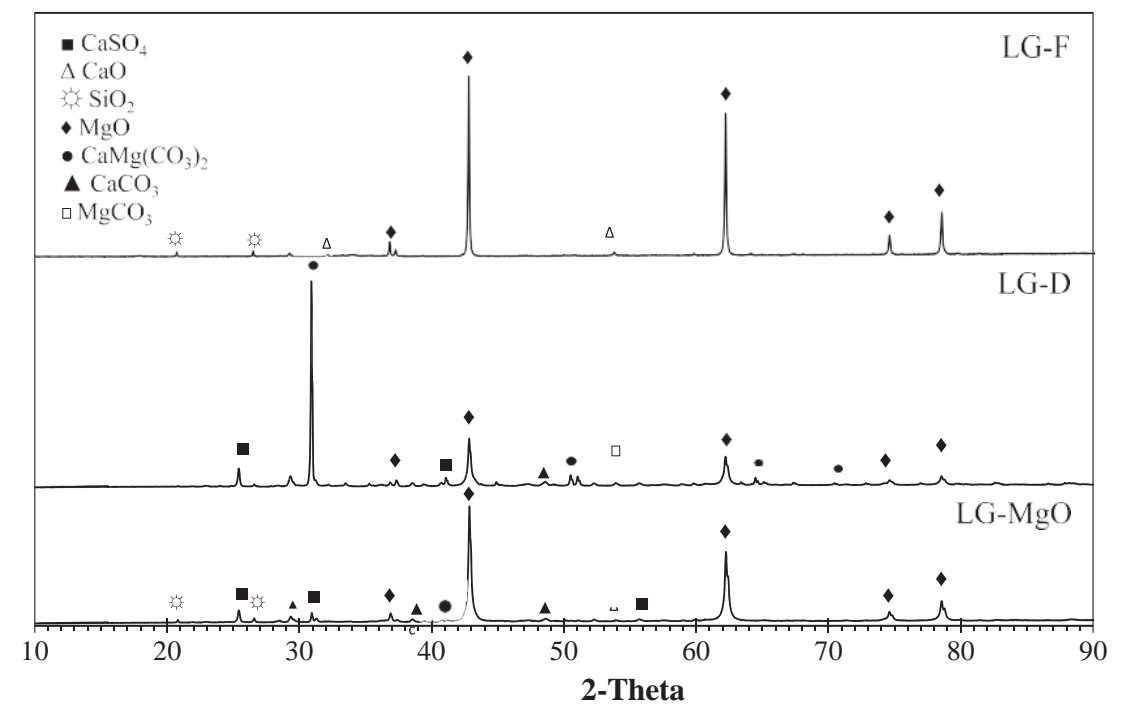

Fig. 1. X-ray pattern of the by-products: LG-MgO, LG-D and LG-F. 

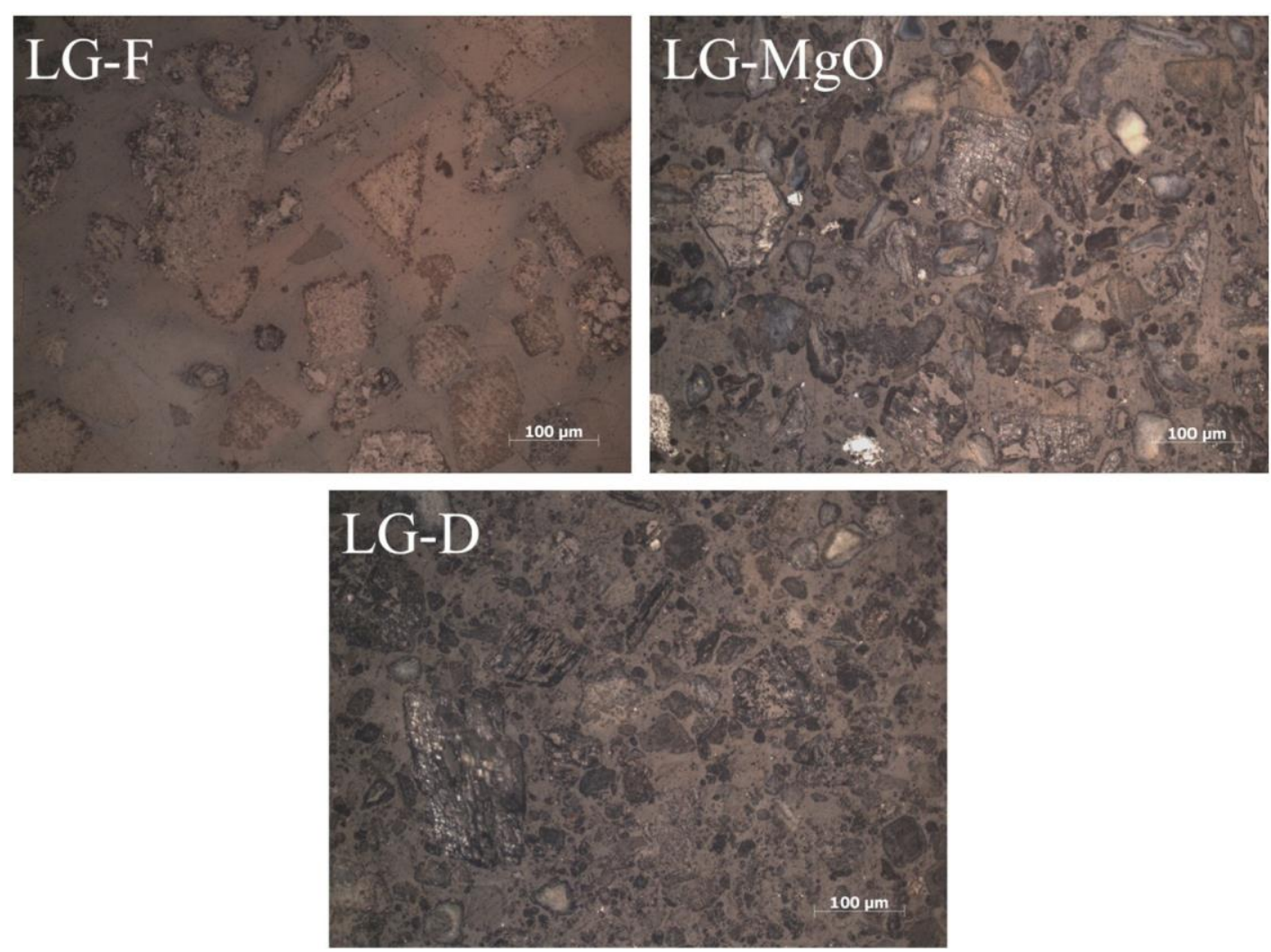

Fig. 2. Optical microscope images of the three by-products.

\subsection{Acid neutralization capacity}

\subsubsection{Neutralization curve}

Fig. 4 shows the neutralization curve $\left(\mathrm{pH} \mathrm{vs} \mathrm{H}_{3} \mathrm{O}^{+}\right.$, per kg of raw material) obtained from the preliminary part of the test for the three by-products. The natural $\mathrm{pH}$ of LG-F and LG-D was close to 12 and controlled by the solubility of the calcium phases, as discussed below.
Unlike these two by-products, the starting $\mathrm{pH}$ of LG-MgO was close to 10.5. As shown, the acid consumption of LG-F was considerably greater, especially in the linear range between the natural $\mathrm{pH}$ and $\mathrm{pH} 8$, at which point a gradual drop was observed. This fall was also observed for LG-MgO and LG-D at the same $\mathrm{pH}$. In these two latter cases, a linear range was also observed although it was shorter than for LG-F, especially in the case of LG-D. The linear section around 9.5 is reported to be

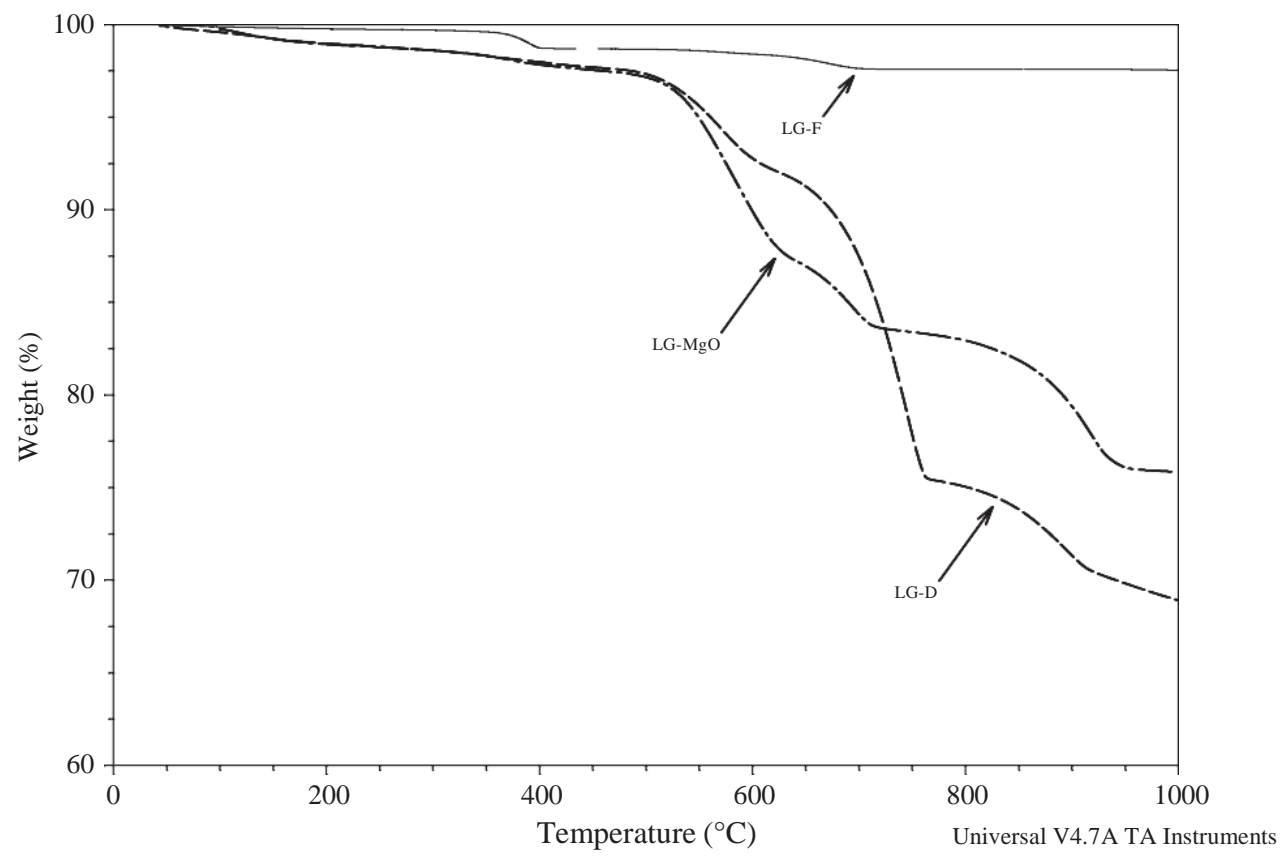

Fig. 3. TG curves of thermal decomposition of LG-MgO, LG-D and LG-F up to $1000^{\circ} \mathrm{C}$ in an inert atmosphere. 
Table 3

Major mineral phases characterization of the by-products from XRF, XRD and TA results.

\begin{tabular}{llcl}
\hline & LG-MgO (\%) & LG-D (\%) & LG-F (\%) \\
\hline $\mathrm{Mg}(\mathrm{OH})_{2}$ & 4.2 & 3.9 & 3.4 \\
$\mathrm{MgCO}_{3}$ & 17.2 & 11.1 & - \\
$\mathrm{CaMg}\left(\mathrm{CO}_{3}\right)_{2}$ & 6.3 & 33.6 & 1.7 \\
$\mathrm{CaCO}_{3}$ & 15.1 & 10.1 & 0.7 \\
$\mathrm{MgSO}_{4}$ & - & 4.6 & - \\
$\mathrm{MgO}$ & 50.1 & 23.5 & 76.7 \\
$\mathrm{CaO}$ & - & 5.9 & 8.6 \\
$\mathrm{CaSO}$ & 1.7 & 3.7 & - \\
Rest & 5.6 & 4.6 & 11.1 \\
\hline
\end{tabular}

mainly controlled by the equilibrium solubility of $\mathrm{Mg}(\mathrm{OH})_{2}$ and therefore by the reactivity of $\mathrm{MgO}$ (Chimenos et al., 2003). As a consequence, the major linear response of $\mathrm{LG}-\mathrm{F}$ can be attributed to its higher $\mathrm{MgO}$ content and also to $\mathrm{Mg}(\mathrm{OH})_{2}$ from hydration reactions, resulting in a large neutralizing capacity in the relatively high $\mathrm{pH}$ range (Yan et al., 2000). The hydration reactions easily reach equilibrium and slow down neutralizing reaction rates. Once these two phases are consumed, the buffering capacity depicted by the descending curye in the $\mathrm{pH}$-4 range can be ascribed to the equilibrium of $\mathrm{HCO}_{3} \mathrm{O}_{3}^{2-}$ (Fernandez et al., 2000). In this respect, it should be emphasized that carbonates are critical buffering minerals in the neutralizing of solid wastes that are characteristic of non-linear behaviour (Kiil et al., 1998; Yan, 1998). Taking into account the low content of magnesium or calcium carbonate in LG-F (see Table 3), the slow decline in $\mathrm{pH}$ from 8 to 4 can be attribut$\mathrm{ed}$, to a certain extent, to the low reactivity of the $\mathrm{MgO}$ content, as previously stated in association with the high temperature and time of calcination to which this by-product was subjected. According to the above, LG-D and LG-F may be used to stabilize slightly acid solid waste or wastewater while $\mathrm{LG}-\mathrm{MgO}$ is more appropriate for residues that are slightly alkaline. In both cases, an excess of these products used as stabilizing agents allows one to obtain a suitable $\mathrm{pH}$ range in which $\mathrm{pH}$-dependent heavy metals and metalloids show minimum solubility (García et al., 2004). In the next section, the abovementioned results are corroborated by comparing them with geochemical predictions.

\subsubsection{Correlation between experimental data and theoretical modelling}

Fig. 5 shows the experimental concentration release (log $\left.\mathrm{mg} k g^{-1}\right)$ and the modelling predictions of $\mathrm{Mg}, \mathrm{Ca}, \mathrm{SO}^{2-}$ and $\mathrm{Fe}$ for $\mathrm{LG}-\mathrm{MgO}$ as a function of $\mathrm{pH}$. The predicted values were relatively consistent with the experimental data, especially for $\mathrm{Mg}$, $\mathrm{Ca}$ and $\mathrm{SQ}^{2-}$. The geochemical modelling confirmed that brucite was the mineral phase controlling magnesium in the 8-10.5 $\mathrm{pH}$ range. As $\mathrm{pH}$ fell below 8, its leaching became non $\mathrm{pH}$-dependent and was mainly controlled by magnesite ( $\mathrm{pH} \mathrm{N}$ 5.5) and then by dolomite ( $\mathrm{pH} \mathrm{N} 4$ ). As for Ca, calcite was identified as the main solubility-controlling mineral in highly alkaline conditions ( $\mathrm{pH}$ N 9.5), while dolomite was more important in the rest of the $\mathrm{pH}$ range. The release of sulphates was entirely controlled by gypsum throughout the $\mathrm{pH}$ range. In the case of $\mathrm{Fe}$, finding a good correspondence between the experimental data and the values predicted by the geochemical modelling required assumptions about the many possible mineral phases that this metal might form (e.g. $\mathrm{Fe}_{2} \mathrm{O}_{3}, \mathrm{Fe}_{3} \mathrm{O}_{4}, \mathrm{FeO}$, etc.), as none could be detected by XRD analysis. The initial assumptions considered one phase only and then different combinations were tested. The best fit was attained by considering $\mathrm{Fe}(\mathrm{OH})_{2}$ as the main iron phase in the solid, with goethite and magnesioferrite suggested as the main solubility-controlling phases for $\mathrm{pH}$ values above 5.5, and ferrihydrate for more acidic conditions $(\mathrm{pH}=4-5.5)$. This was corroborated by XRD analysis (not shown) of the solids resulting from the ANC test, as the dissolution of the major phases allowed identification of the minor phases of iron. The presence of ferrihydrate at $\mathrm{pH} 4.5$ confirmed that
leaching of iron at this pH is controlled by this phase as predicted by the software. Some iron hydroxides that had not yet completely dissolved were also detected in the solid. The same conclusion can be drawn from the XRD pattern of the solid at $\mathrm{pH}$ 6.5, in which magnesioferrite was identified together with hematite and magnetite.

The corresponding results for LG-D are shown in Fig. 6. Again, good correspondence between both types of data was observed for the alkaline elements and sulphates in solution. The mineral phases controlling magnesium and calcium solubility were the same as in the LG-MgO case, with an additional influence of $\mathrm{CaSO}_{4}$ on calcium solubility at $\mathrm{pH}$ values under 9. Sulphate release was higher than in LG-MgO and its solubility was mainly controlled by $\mathrm{CaSO}_{4}$ and additionally by elemental sulphur, whose source is most likely the petcoke. The Fe mineral phase was again attributed to $\mathrm{Fe}(\mathrm{OH})_{2}$, whose potential solubility-controlling minerals at very acidic $\mathrm{pH}$ values $\left(\mathrm{pH}\right.$ b 5) were both $\mathrm{Fe}(\mathrm{OH})_{8}$ and ferrihydrite, while $\mathrm{Fe}(\mathrm{OH})_{2}$ was responsible at $\mathrm{pH}$ values over 5 .

The fit between experimental data and modelling predictions for LG-F (Fig. 7) was again very high for $\mathrm{Mg}$ and $\mathrm{Ca}$. The control of magnesium leaching by brucite was more pronounced. As in LG-MgO, an additional effect of calcite on calcium solubility was suggested by the model, although in the 5-10 $\mathrm{pH}$ range. The release of sulphates was much

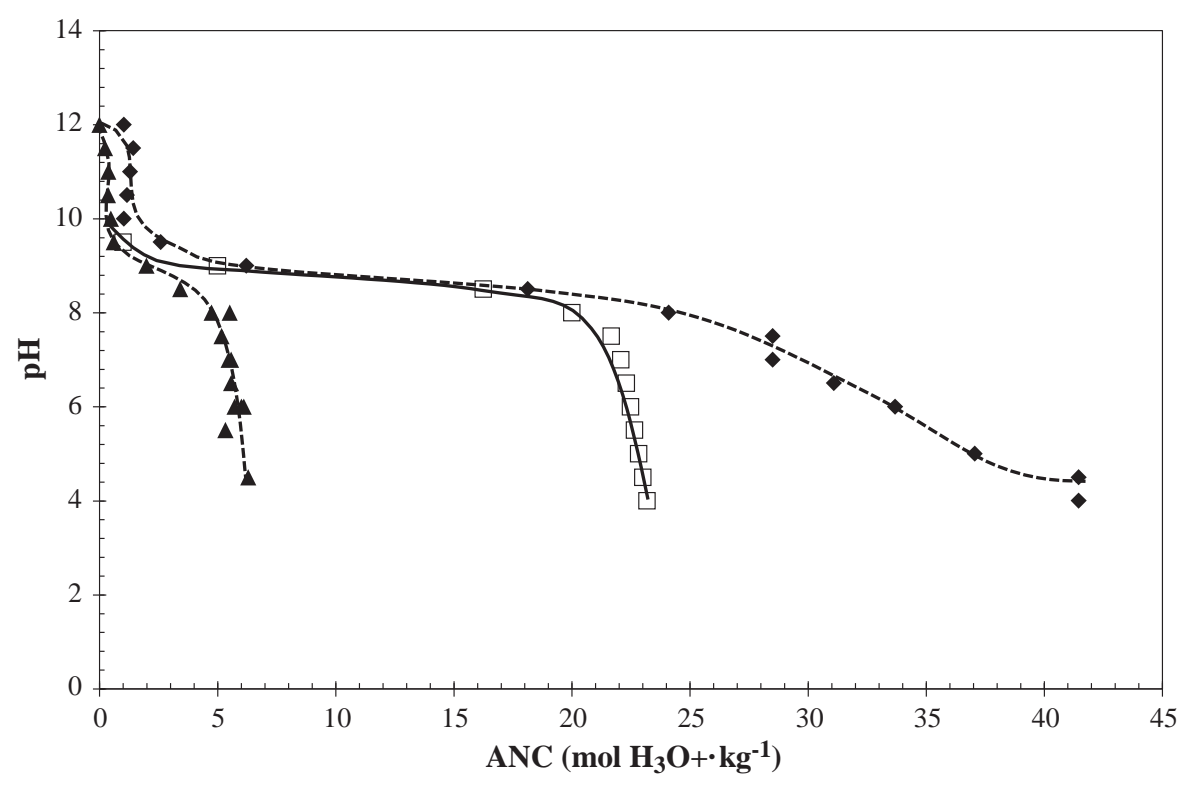

Fig. 4. $\mathrm{pH}$ as a function of acid consumption $\left(\mathrm{H}_{3} \mathrm{O}^{+\bullet} \mathrm{kg}^{-1}\right)$ for the three by-products $(\bullet \mathrm{LG}-\mathrm{F}, \square \mathrm{LG}-\mathrm{MgO}, \boldsymbol{\Lambda} \mathrm{LG}-\mathrm{D})$. 

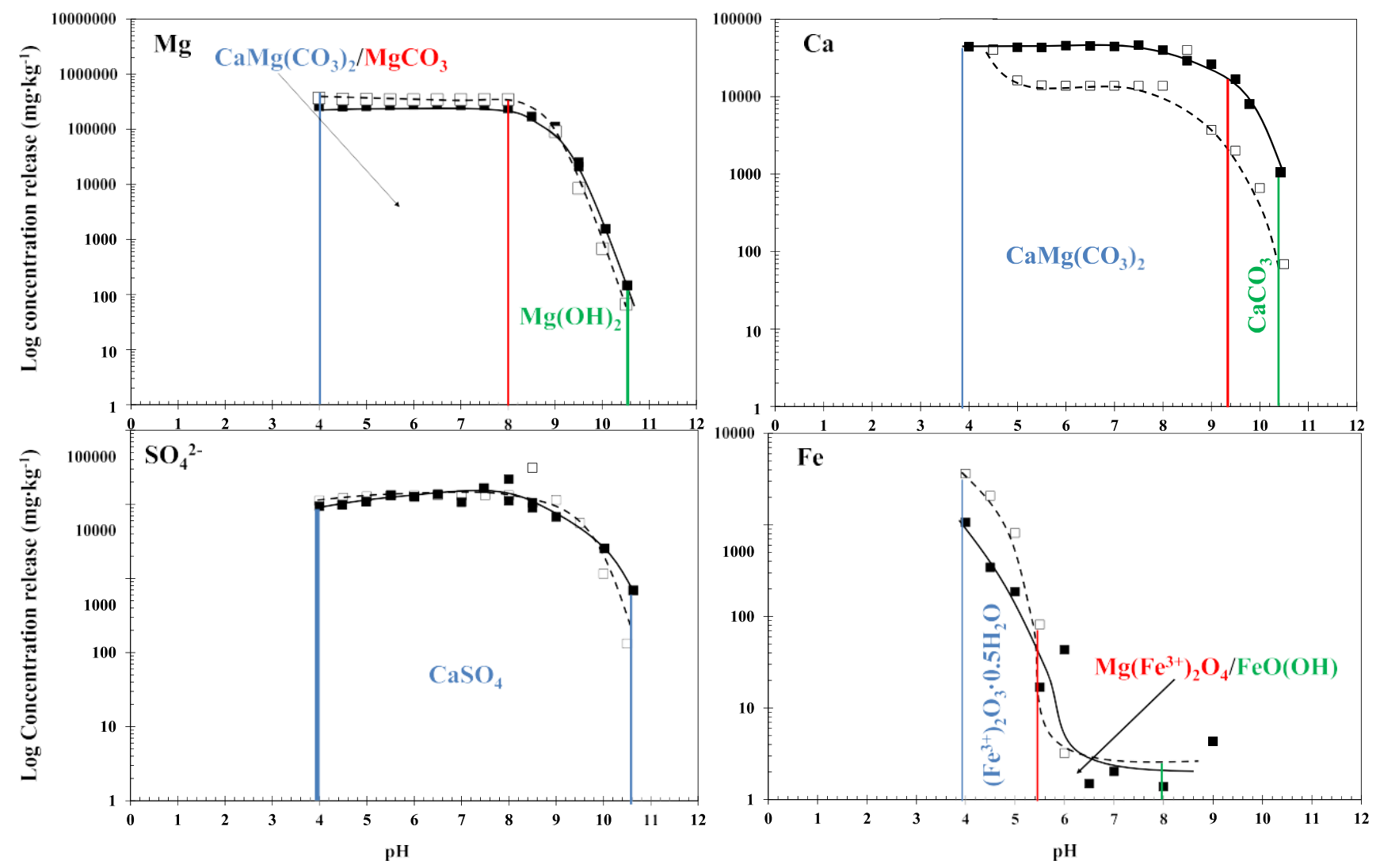

Fig. 5. Concentration release of $\mathrm{Mg}, \mathrm{Ca}, \mathrm{SO}_{\longleftarrow}^{2}$ and Fe (log $\left.\mathrm{mgkg}-1\right)$ as a function of pH for LG-MgO: correlation between experimental data ( $\left.\mathbf{\square}\right)$ and geochemical modelling predictions ( $\square$ ).

lower than that of the other two by-products and the suggested solubility-controlling mineral was gypsum. In this respect, $\mathrm{CaSO}_{4}$ was not detected in LG-F during characterization and therefore sulphate release might be attributed to sulphur petcoke species not included in the model. Although the XRF analysis showed a small amount of Fe in LG-F (not detectable by XRD), the analysis of the eluates showed that leaching of iron was close to the detection limit, indicating the insolubility of its bearing phase in this by-product. Hence, obtaining experimental leaching data for Fe was not feasible and neither was comparison with geochemical predictions. However, as before, the decrease in $\mathrm{pH}$ allowed the major phases to dissolve and therefore improved the identification of minor phases by XRD analysis. The results (not shown) indicated that the final solid at $\mathrm{pH} 4$ is basically a mixture of $\mathrm{SiO}_{3}, \mathrm{Fe}_{3} \mathrm{O} 4$ and $\mathrm{Fe}_{2} \mathrm{O}_{3}$. Both $\mathrm{Fe}$-bearing phases were detectable at $\mathrm{pH}$ values under 8 . Thus, these three mineral phases are not soluble, supporting theresultsobtained from the analysis of the eluates.

\subsubsection{Leaching percentage and reutilization potential}

Taking into account the total content and the maximum concentration of each metal released, it is possible to calculate the leaching percentage $(\% \mathrm{~L})$ and the metal availability as a function of $\mathrm{pH}$.

Magnesium release was the highest for all by-products, with maximum values of $460.4,276.5$ and $187.5 \mathrm{~g}^{\mathrm{kg}}{ }^{-1}$ at a $\mathrm{pH}=4$ for LG-F, LG-MgO and LG-D, respectively. These values represent 96.6, 75.4 and $67.7 \% \mathrm{~L}$. Hence, almost all the magnesium content is available for leaching in the case of LG-F. In the case of LG-D, other less reactive magnesium phases (e.g. $\mathrm{MgCO}_{3}$ or $\left.\mathrm{CaMg}\left(\mathrm{CO}_{3}\right)_{2}\right)$ limited its buffering capacity. A common behaviour of intense $\mathrm{Mg}$ leaching was observed in the $\mathrm{pH}$ 8-10 range for the three by-products (Figs. 5 to 7), coinciding with the linear response mentioned above (Fig. 4). This can be attributed to the rapid consumption of $\mathrm{OH}^{-}$from the $\mathrm{MgO} / \mathrm{Mg}(\mathrm{OH})_{2}$ system. However, while magnesium release remained constant for LG-D and
LG-MgO at $\mathrm{pHs}$ lower than 8, the leaching of magnesium increased slightly for LG-F. A higher degree of sinterization for LG-F might be responsible for the slow magnesium release below $\mathrm{pH} 8$, which also slowed down the decline in $\mathrm{pH}$ in this interval (see Fig. 4).

Calcium release varies widely consistent with its multiple modes of occurrence (Izquierdo et al., 2011). For LG-D maximum release occurred from $\mathrm{pH} 11.5$ to 9 , with a maximum concentration of $76-85 \mathrm{~g}^{\mathrm{kg}} \mathrm{k}^{-1}$ released by the end of the test $(\mathrm{L} \%=54.5)$. The corresponding maximum concentration released from LG-F and LG-MgO was 53.6 and $45.5 \mathrm{~g} k g^{-1}(\mathrm{~L} \%=64.4$ and $\mathrm{L} \%=71.6)$ respectively. According to the geochemical predictions, the sharp lixiviation release of $\mathrm{Ca}^{2+}$ can be attributed to $\mathrm{CaCO}_{3}$ and $\mathrm{CaMg}\left(\mathrm{CO}_{3}\right)_{2}$, with additional influence from $\mathrm{CaSO}_{4}$ in the case of LG-D. Thus, while the release of $\mathrm{Ca}^{2+}$ from LG-F was relatively constant across the whole $\mathrm{pH}$ range because the content of both carbonated phases was negligible, the contribution of these phases to the buffering capacity of LG-MgO was significant, being the only two contributing phases. However, for the LG-D by-product, the increase in $\mathrm{Ca}^{2+}$ release continued until $\mathrm{pH} 4$, revealing that $\mathrm{CaCO}_{3}$ and $\mathrm{CaMg}\left(\mathrm{CO}_{3}\right)_{2}$, the levels of which are significant in LG-D, were subsequently the main controlling phases.

The results of Fe lixiviation from LG-MgO and LG-D showed that the release of this metal remained virtually unchanged until a $\mathrm{pH}$ of 5 was reached, at which point substantial release was observed for both materials. The low solubility of Fe mineral phases assured its immobilization and stability at $\mathrm{pH}$ values over 5 . Unlike the oxides contained in sediments or in natural soils, the iron oxides in these by-products are sintered at high temperatures and, consequently, had very low solubility (Chimenos et al., 2012). Unlike calcium and magnesium, the $\% \mathrm{~L}$ was very low, at 5.8 and 1.1 for LG-MgO and LG-D, respectively. The difference between these two by-products can be attributed to the presence of a more stable Fe phase (most probably $\mathrm{Fe}(\mathrm{OH})_{8}$ or ferrihydrate, according to Visual MINTEQ). It is at very acidic conditions 

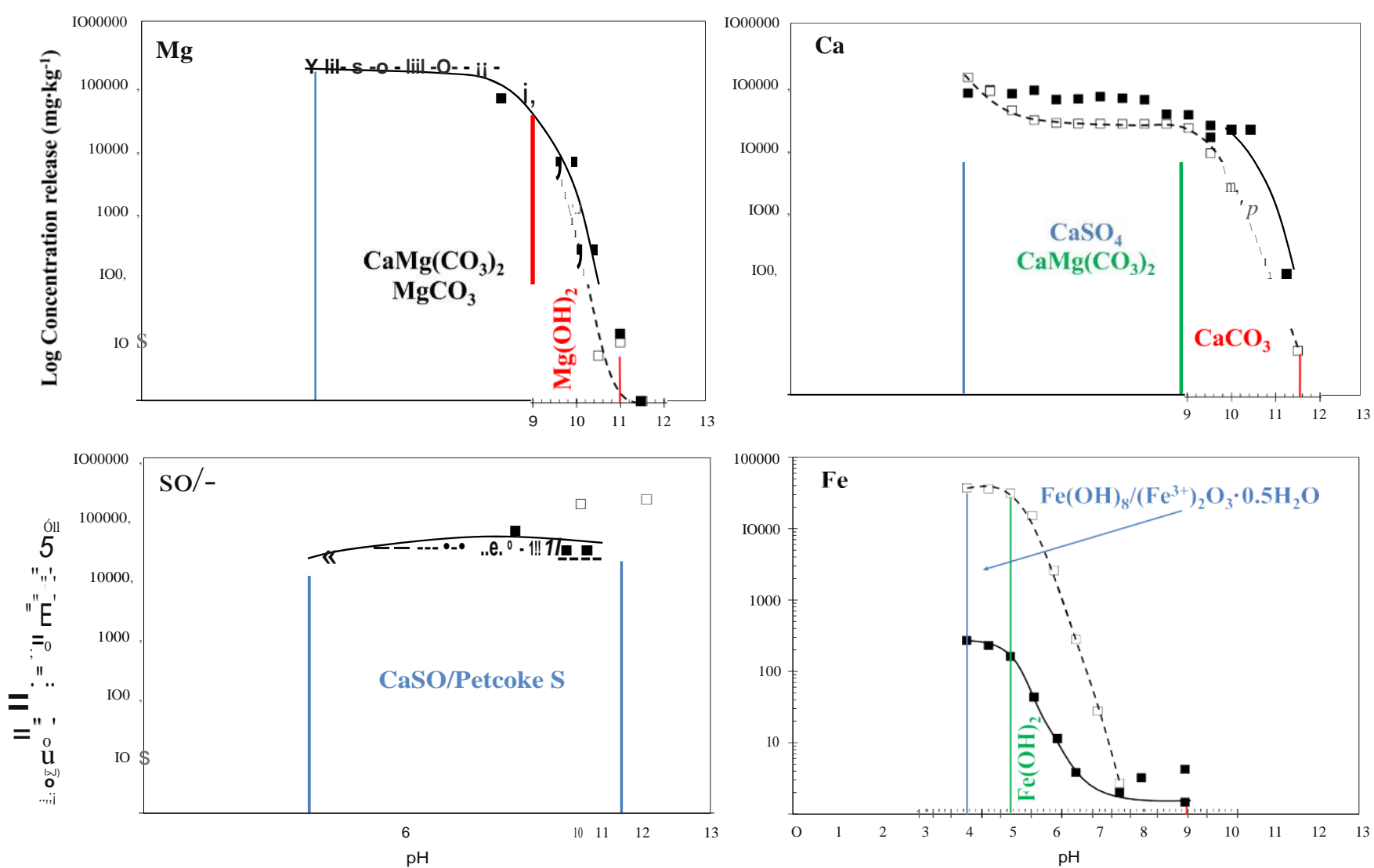

Fig. 6. Concentration release of $\mathrm{Mg}, \mathrm{Ca}, \mathrm{SO}_{4}^{2}$ and Fe (log mgrkg-1) as a function of pH for LG-D: correlation between experimental data ( $\square$ ) and geochemical modelling predictions ( $\square$ ).

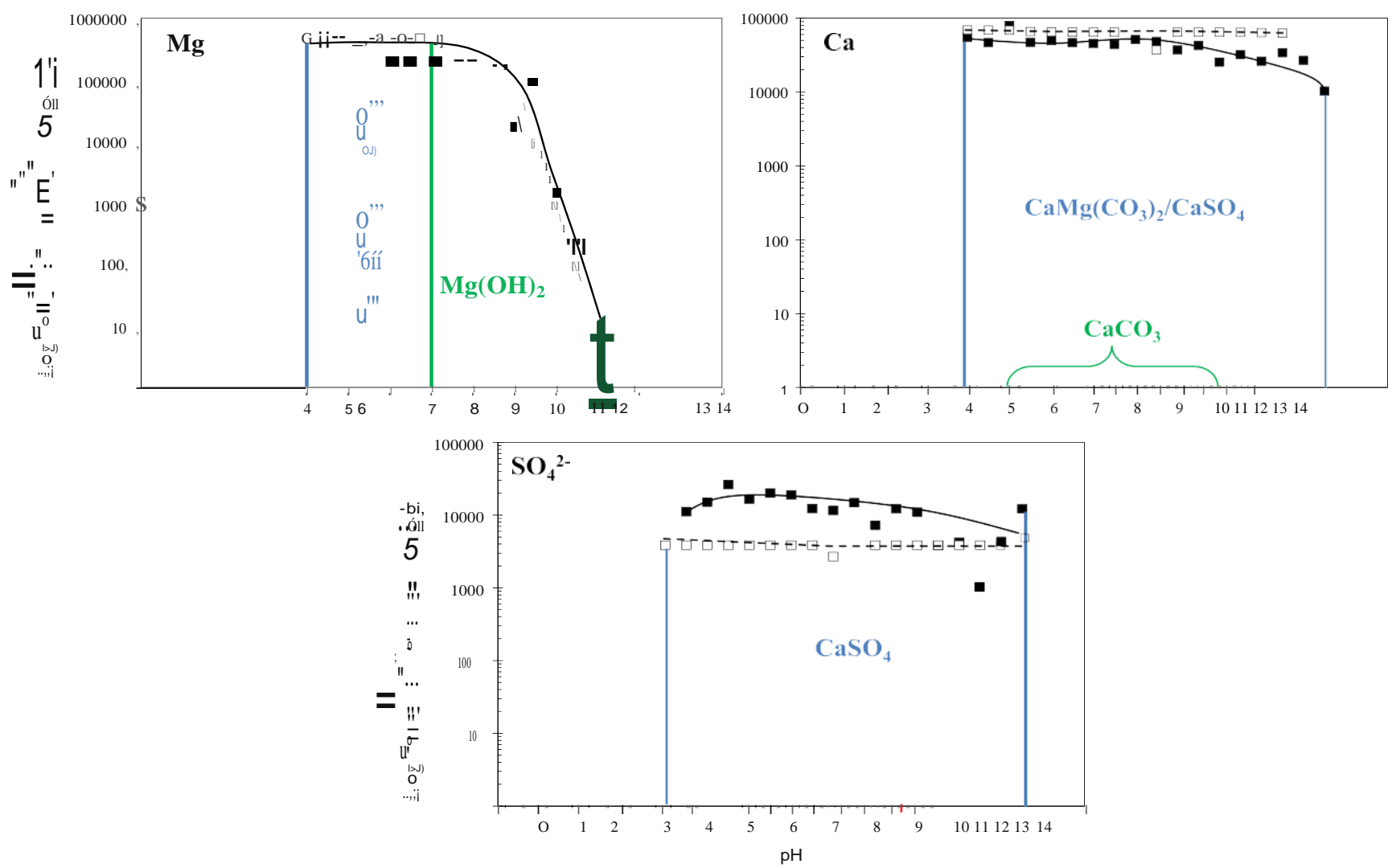

Fig. 7. Concentration release of $\mathrm{Mg}$, Ca and $\mathrm{SO}_{4}^{2}\left(\log \mathrm{mg}_{\mathrm{kg}}{ }^{-1}\right)$ as a function of $\mathrm{pH}$ for LG-F: correlation between experimental data $(\boldsymbol{\square})$ and geochemical modelling predictions $(\square)$. 
$(\mathrm{pH} \approx 4)$ that the majority of Feis leached. Therefore, the use of these by-products at a $\mathrm{pH}$ range above 6 guarantees an alkali reservoir $\left(\mathrm{Ca}^{2+}\right.$ and $\left.\mathrm{Mg}^{2+}\right)$ without Feleaching.

The release of sulphates was higher in LG-D than in the other two by-products and showed a maximum concentration release $\left(43.3 \mathrm{~g} \cdot \mathrm{kg}^{-1}\right)$ at $\mathrm{pH}$ 6, equivalent to approximately $17.4 \% \mathrm{~L}$. Unlike LG-D, leaching of sulphates in LG-MgO was $\mathrm{pH}$-dependent and intense leaching was observed in the 11-6 $\mathrm{pH}$ range (an average of 21.5 $\mathrm{grkg}^{-1}$ ) with a \% Lof $8.8 \%$, lower than that forLG-D. Asmentionedabove, the differences between theleaching profile ofLG-MgOandLG-Dindicate that the source of sulphur in each by-product might differ. On the one hand, LG-D contained significant amounts of $\mathrm{MgSO}_{4}$ and $\mathrm{CaSO}_{4}$ and therefore its maximum leaching reflected their solubility in the 8-10 $\mathrm{pH}$ range. This was supported by geochemical modelling, which also suggested elemental sulphur as the solubility-controlling species. On the other hand, the lower $\mathrm{CaSO}_{4}$ content in LG-MgO alludes to the fact that elemental sulphur bonded to organic ligands (not predicted by geochemical modelling) is the most probable source of sulphates from LG-MgO, hence the different leaching behaviour in response to $\mathrm{pH}$. The leaching of sulphates from LG-F was lower than that from the dust materials and the $\% \mathrm{~L}$ was $100 \%$. The release of sulphates can mainly be attributed to the use of petcoke as a fossil fuel in the calcination of natural magnesite. During the industrial process, some of the petcoke sulphur produces sulphur dioxide $\left(\mathrm{SO}_{2}\right)$ during combustion and reacts by means of direct sulphation with magnesium and/or calcium oxides, forming magnesium and calcium sulphates, respectively. If the temperature or the residence time inside the furnace is lower than those required for decomposition, both types of sulphates remain in the solid phase. Moreover, the rest of the unreacted petcoke sulphur could remain in the solid particles as well.

In order to describe the role that the phases of LG-F play in ANC, Figs. 8 and 9 show the TGA curves of the resulting solid at each final $\mathrm{pH}$ of the leaching experiments. Fig. 8 shows the corresponding curves from natural to $\mathrm{pH}$ 8. For better comprehension of the decomposition curves, this figure was divided into two. The reduced image in the lower left corner of the figure represents a magnified picture of curves at $\mathrm{pH} 12,11.5,11,10.5,10$ and 9.5, which remained very close to each other. Hydration of $\mathrm{CaO}$ and $\mathrm{MgO}$ took place at alkaline $\mathrm{pH}$ values, especially from $\mathrm{pH} 12$ to 9.5 , as seen in the decomposition curves of $\mathrm{Mg}(\mathrm{OH})_{2}$ and $\mathrm{Ca}(\mathrm{OH})_{2}$ at temperatures under $500{ }^{\circ} \mathrm{C}$. As mentioned above, the linear response at pH N 9 can be attributed to the solubility equilibrium of $\mathrm{Mg}(\mathrm{OH})_{2} / \mathrm{MgO}$ and at a higher $\mathrm{pH}$ to $\mathrm{Ca}(\mathrm{OH})_{2} / \mathrm{CaO}$. At $\mathrm{pH}$ values under 9.5, the hydroxide phases dissolved as a consequence of the acid additions, and the corresponding decomposition curves of $\mathrm{MgCO}_{3}\left(500-600{ }^{\circ} \mathrm{C}\right)$ and $\mathrm{CaMg}\left(\mathrm{CO}_{3}\right)_{2}$ started to disappear, indicating the buffering role that this pair played at $\mathrm{pH} b \mathrm{~b}$. The mass loss steps observed for $\mathrm{pH} 8.5$ and 8 at temperatures less than $300^{\circ} \mathrm{C}$ can be attributed to moisture loss and water of crystallization, which formed in a different manner as the availability of major cations varied. In this respect, Fig. 9 shows the corresponding curves for $\mathrm{pH} 7.5$ to 4 . The zone of the superimposed curves at temperatures under $300{ }^{\circ} \mathrm{C}$ can again be attributed to water crystallization. The mass loss between 300 and $400{ }^{\circ} \mathrm{C}$ observed for all curves can be attributed to the decomposition of $\mathrm{Mg}(\mathrm{OH})_{2}$ with the absence of any other major phase.

\section{Conclusions}

The reuse of by-products from the calcination of natural magnesite is conditioned by the availability of $\mathrm{MgO}, \mathrm{CaO}$ and the leaching of the main impurities: Fe and S. In this study, three types of by-products were assessed (LG-MgO, LG-D, and LG-F). The alkali reservoir, which is mainly dependent on the availability of $\mathrm{Mg}$ and $\mathrm{Ca}$, was assessed by the acid neutralization capacity (ANC) test. The release of Fe and SO2was also evaluated in order to environmentally delimit the reutilization of these by-products. The experimental data obtained from the ANC test was compared to geochemical predictions using the software Visual

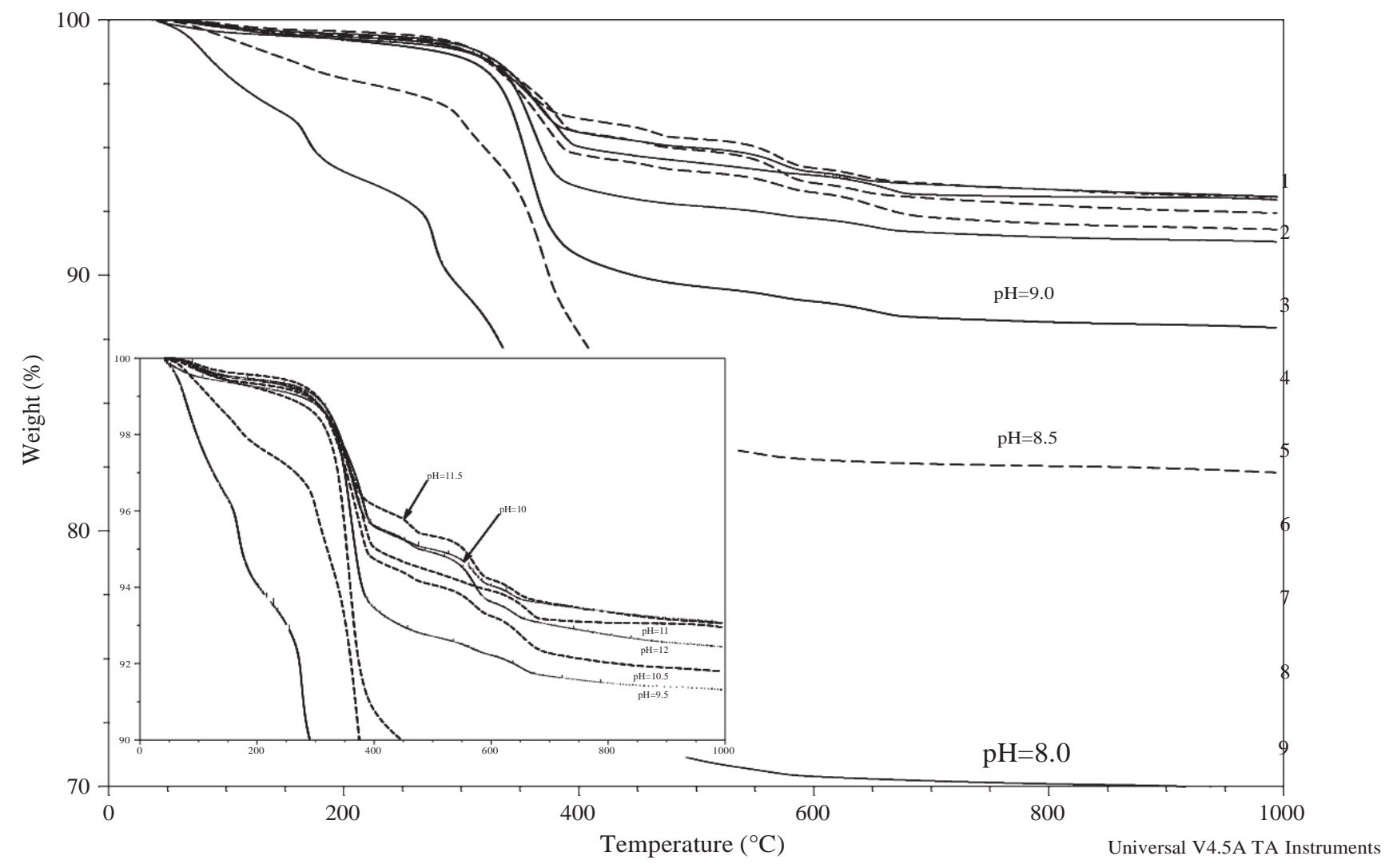

Fig. 8. Decomposition curves (mass loss percentage vs. temperature) of LG-F as a function of $\mathrm{pH}$ (from natural $\mathrm{pH}$ to 8 ). 


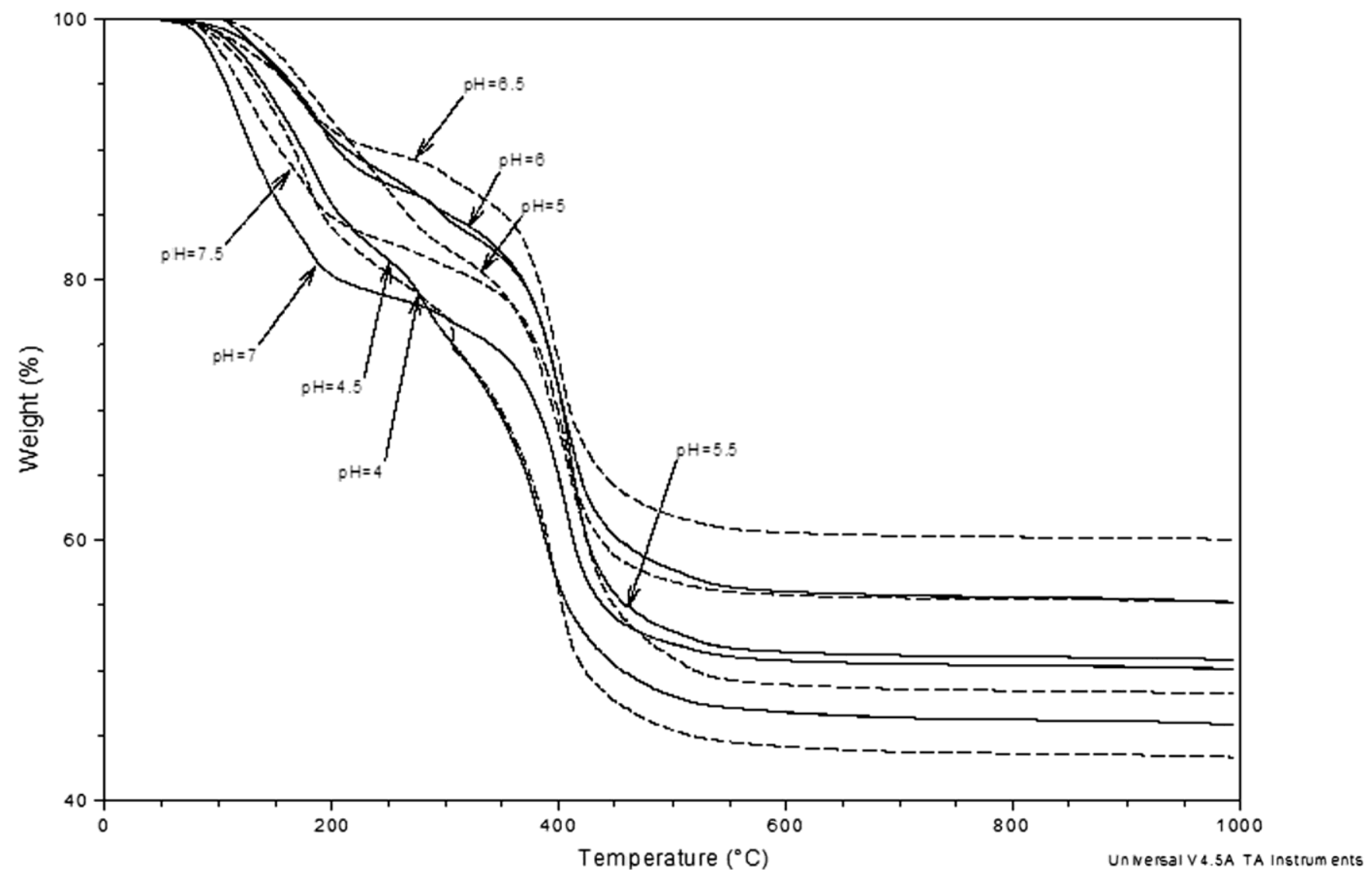

Fig. 9. Decomposition curves (mass loss percentage vs. temperature) of LG-F as a function of pH (from pH 8 to 4).

MINTEQ. Unlike in other studies, the modelling approach was based on each solid's chemical characterization, with trial and error used to fit the model in the case of $\mathrm{Fe}$, as the bearing phases in the raw by-products were not detectable by XRD analysis. The experimental data from all by-products fitted well with the geochemical predictions. Buffer capacity is directly related to the content of $\mathrm{MgO}$, with an additional contribution from other alkaline phases (e.g. $\mathrm{CaCO}_{3}$ and $\mathrm{CaSO}_{4}$ ) present in the by-products. In this sense, linear behaviour was observed within the $8-10 \mathrm{pH}$ range, mainly dominated by the neutralization of $\mathrm{MgO} / \mathrm{Mg}(\mathrm{OH})_{2}$ equilibrium with a small contribution at lower $\mathrm{pH}$ values from the carbonates contained within the by-products. The release of sulphates showed non-pH dependency and was higher in the dust materials than LG-F, being attributed to the solubility of $\mathrm{CaSO}_{4}$ and elemental sulphur present in petcoke. For dust materials, leaching of $\mathrm{Fe}$ was minimal below $\mathrm{pH} 4$ and under the detection limit for LG-F, owing to the insoluble nature of the $\mathrm{Fe}_{2} \mathrm{O}_{3} / \mathrm{Fe}_{3} \mathrm{O}_{4}$ pair. Accordingly, the by-products labeled as LG-D and LG-F are better suited for stabilizing solid wastes or wastewater that are acid while LG-MgO is more appropriate for alkaline residues such as contaminated soils. The use of these by-products guarantees an environmentally friendly alkali reservoir for the long-term stabilization of heavy metals and metalloids at a very competitive price as a substitute for the widely used lime.

\section{Acknowledgements}

The authors would like to thank Magnesitas Navarras, S.A. for their financial support, Ms. Judith Gómez for technical assistance and Dr. Alberto Coz from the University of Cantabria for help with the geochemical modelling. Ricardo del Valle Zermeño is grateful to the Government of Catalonia for research grant FI-DGR 2014.

\section{References}

Allison, J.D., Brown, D.S., 1991. MINTEQA2/PRODEFA2, A Geochemical Assessment Model for Environmental Systems: Version 3.11 databases and Version 3.0 User's Manual.

Aphane, M.E., Van Der Merwe, E.M., Strydom, C.A., 2009. Influence of hydration time on the hydration of $\mathrm{MgO}$ in water and in a magnesium acetate solution. J. Therm. Anal. Calorim. 96, 987-992.

Birchal, V.S.S., Rocha, S.D.F., Ciminelli, V.S.T., 2000. Effect of magnesite calcination conditions on magnesia hydration. Miner. Eng. 13, 1629-1633.

Cappuyns, V., Swennen, R., Verhulst, J., 2004. Assessment of acid neutralizing capacity and potential mobilisation of trace metals from land-disposed dredged sediments. Sci. Total Environ. 333, 233-247.

Chimenos, J.M., Fernández, A.I., Villalba, G., Segarra, M., Urruticoechea, A., Artaza, B. Espiell, F., 2003. Removal of ammonium and phosphates from wastewater resulting from the process of cochineal extraction using. Water Res. 37, 1601-1607.

Chimenos, J., Fernandez, A., Hernandez, A., 2006. Optimization of phosphate removal in anodizing aluminium wastewater. Water Res. 40, 137-143.

Chimenos, J.M., Fernández, a I., Haurie, L., Calaf, M., 2012. Trace metal partitioning in caustic calcined magnesia produced from natural magnesite. J. Environ. Sci. Health A Toxic Hazard. Subst. Environ. Eng. 47, 93-100.

Cortina, J.-L., Lagreca, I., De Pablo, J., Cama, J., Ayora, C., 2003. Passive in situ remediation of metal-polluted water with caustic magnesia: evidence from column experiments. Environ. Sci. Technol. 37, 1971-1977.

Cubukcuoglu, B., Ouki, S.K., 2012. Solidification/stabilisation of electric arc furnace waste using low grade $\mathrm{MgO}$. Chemosphere 86, 789-796.

Del Valle-Zermeño, R., Chimenos, J.M., Formosa, J., Fernández, A.I., 2012. Hydration of a low-grade magnesium oxide. Lab-scale study. J. Chem. Technol. Biotechnol. 87, 1702-1708.

Demir, F., Dönmez, B., Okur, H., Sevim, F., 2003. Calcination kinetic of magnesite from thermogravimetric data. Chem. Eng. Res. Des. 81, 618-622.

Demir,F.,Laçin, O., Dönmez, B., 2006. Leachingkinetics of calcined magnesitein citricacid solutions. Ind. Eng. Chem. Res. 45, 1307-1311.

Fernández, A.I., Chimenos, J.M., Segarra, M., Fernández, M.A., Espiell, F., 1999. Kinetic study of carbonation of MgO slurries. Hydrometallurgy 53, 155-167.

Fernández, A.I., Chimenos, J.M., Segarra, M., Fernández, M.A., Espiell, F., 2000. Procedure to obtain hydromagnesite from a $\mathrm{MgO}$-containing residue. Kinetic study. Ind. Eng. Chem. Res. 39, 3653-3658.

Fernández, A.I., Chimenos, J.M., Raventós, N., Miralles, L., Espiell, F., 2003. Stabilization of electrical arc furnace dust with low-grade $\mathrm{MgO}$ prior to landfill. J. Environ. Eng. 129, 275-279. 
Fernández, A.I., Haurie, L., Formosa, J., Chimenos, J.M., Antunes, M., Velasco, J.I., 2009 Characterization of poly(ethylene-co-vinyl acetate) (EVA) filled with low grade magnesium hydroxide. Polym. Degrad. Stab. 94, 57-60.

Formosa, J., Chimenos, J.M., Lacasta, A.M., Haurie, L., 2011. Thermal study of low-grade magnesium hydroxide used as fire retardant and in passive fire protection. Thermochim. Acta 515, 43-50.

Formosa, J., Chimenos, J.M., Lacasta, A.M., Niubó, M., 2012. Interaction between low-grade magnesium oxide and boric acid in chemically bonded phosphate ceramics formulation. Ceram. Int. 38, 2483-2493.

Förstner, U., Haase, I., 1998. Geochemical demobilization of metallic pollutants in solid waste-implications for arsenic in waterworks sludges. J. Geochem. Explor. 62, 29-36.

García, M.A.,Chimenos, J.M.,Fernández,A.I.,Miralles, L.,Segarra, M.,Espiell, F. 2004.Lowgrade $\mathrm{MgO}$ used to stabilize heavy metals in highly contaminated soils. Chemosphere 56, 481-491.

González-Núñez, R., Alba, M.D., Orta, M.M., Vidal, M., Rigol, A., 2012. Remediation of metal-contaminated soils with the addition of materials - Part II: leaching tests to evaluate the efficiency of materials in the remediation of contaminated soils. Chemosphere 87, 829-837.

Ho, H.H., Swennen, R., Cappuyns, V., Vassilieva, E., Van Gerven, T., Tran, T. Van, 2012. Potential release of selected trace elements ( $\mathrm{As}, \mathrm{Cd}, \mathrm{Cu}, \mathrm{Mn}, \mathrm{Pb}$ and $\mathrm{Zn}$ ) from sediments in Cam River-mouth (Vietnam) under influence of $\mathrm{pH}$ and oxidation. Sci. Total Environ. 435-436, 487-498.

Houben, D., Pircar, J., Sonnet, P., 2012. Heavy metal immobilization by cost-effective amendments in a contaminated soil: effects on metal leaching and phytoavailability. J. Geochem. Explor. 123, 87-94.

Izquierdo, M., Koukouzas, N., Touliou, S., Panopoulos, K.D., Querol, X., Itskos, G., 2011. Geochemical controls on leaching of lignite-fired combustion by-products from Greece. Appl. Geochem. 26, 1599-1606.

Jeong, S.Y., Wagh, A.S., 2003. Cementing the gap between ceramics, cements, and polymers. Mater. Technol. 18, 162-168.

Jung, H.-B., Yun, S.-T., Kwon, J.-S., Zheng, Y., 2012. Role of iron colloids in copper speciation during neutralization in a coastal acid mine drainage, South Korea: insight from voltammetric analyses and surface complexation modeling. J. Geochem. Explor. 112, 244-251.

Kiil, S., Michelsen, M.L., Dam-johansen, K., 1998. Experimental Investigation and Modeling of a Wet Flue Gas Desulfurization Pilot Plant. 5885, 2792-2806.

Meima, J.A., Comans, R.N.J., 1997. Geochemical modeling of weathering reactions in municipal solid waste incinerator bottom ash. Environ. Sci. Technol. 31, 1269-1276.

Meima, J.A., Comans, R.N.J., 1999. The leaching of trace elements from municipal solid waste incinerator bottom ash at different stages of weathering. Appl. Geochem. 14, $159-171$

Meima, J.A., Van Zomeren, A., Comans, R.N.J., 1999. Complexation of Cu with dissolved organic carbon in municipal solid waste incinerator bottom ash leachates. Environ. Sci. Technol. 33, 1424-1429.

Merrikhpour, H., Jalali, M., 2013. The effects of road salt application on the accumulation and speciation of cations and anions in an urban environment. Water Environ. J. 27, 524-534

Navarro, A., Chimenos, J.M., Muntaner, D., Fernández, A.I., 2006. Permeable reactive barriers for the removal of heavy metals: lab-scale experiments with low-grade magnesium oxide. Groundw. Water Monit. Remediat. 26, 142-152.
Neal, C., Reynolds, B., Robson, A., 1999. Acid neutralisation capacity measurements within natural waters: towards a standardised approach. Sci. Total Environ. 243-244, 233-241.

Ohno, M., Ito, M., Ohkura, R., Mino, A.E.R., Kose, T., Okuda, T., Nakai, S., Kawata, K., Nishijima, W., 2014. Photochemical decomposition of perfluorooctanoic acid mediated by iron in strongly acidic conditions. J. Hazard. Mater. 268, 150-155.

Peng, J., Song, Y., Yuan, P., Cui, X., Qiu, G., 2009. The remediation of heavy metals contaminated sediment. J. Hazard. Mater. 161, 633-640.

Rao, A.J., Pagilla, K.R., Wagh, A.S., 2000. Stabilization and solidification of metal-laden wastes by compaction and magnesium phosphate-based binder. J. Air Waste Manag. Assoc. 50, 1623-1631.

Rötting, T.S., Cama, J., Ayora, C., Cortina, J.-L., De Pablo, J., 2006. Use of caustic magnesia to remove cadmium, nickel, and cobalt from water in passive treatment systems: column experiments. Environ. Sci. Technol. 40, 6438-6443.

Salomão, R., Bittencourt, L.R.M., Pandolfelli, V.C., 2007. A novel approach for magnesia hydration assessment in refractory castables. Ceram. Int. 33, 803-810.

Shand, M.A., 2006. The Chemistry and Technology of Magnesia. The Chemistry and Technology of Magnesia. http://dx.doi.org/10.1002/0471980579.

Shi, Z., Allen, H.E., Di Toro, D.M., Lee, S.-Z., Harsh, J.B., 2013. Predicting PbII adsorption on soils: the roles of soil organic matter, cation competition and iron (hydr)oxides. Environ. Chem. 10, 465-474.

Sjöstedt, C., Andrén, C., Fölster, J., Gustafsson, J.P., 2013. Modelling of pH and inorganic aluminium after termination of liming in 3000 Swedish lakes. Appl. Geochem. 35, 221-229.

Strydom, C.A., Van Der Merwe, E.M., Aphane,M.E., 2005. The effect ofcalcining conditions on the rehydration of dead burnt magnesium oxide using magnesium acetate as a hydrating agent. J. Therm. Anal. Calorim. 80, 659-662.

Van Herreweghe, S., Swennen, R., Cappuyns, V., Vandecasteele, C., 2002. Chemical associations of heavy metals and metalloids in contaminated soils near former ore treatment plants: a differentiated approach with emphasis on pHstat-leaching. J. Geochem. Explor. 76, 113-138.

Wagner, a., Kaupenjohann, M., 2014. Suitability of biochars (pyro- and hydrochars) for metal immobilization on former sewage-field soils. Eur. J. Soil Sci. 65, 139-148.

Yan, J., 1998. Major Leaching Processes of Combustion Residues-Characterisation, Modelling and Experimental Investigation. Royal Institute of Technology, Stockholm, Sweden.

Yan, J., Moreno, L., Neretnieks, I., 2000. The long-term acid neutralizing capacity of steel slag. Waste Manag. 20, 217-223.

Yao, Z., Li, J., Xie, H., Yu, C., 2012. Review on remediation technologies of soil contaminated by heavy metals. 7th Int. Conf. Waste Manag. Technol. Procedia Environ. Sci. 16, p. 722

Yu, X.-Z., Wang, D.-Q., Zhang, X.-H., 2014. Chelator-induced phytoextraction of zinc and copper by rice seedlings. Ecotoxicology $1-8$.

Zhu, J., Ye, N., Liu, J., Yang, J., 2013. Evaluation on hydration reactivity of reactive magnesium oxide prepared by calcining magnesite at lower temperatures. Ind. Eng. Chem. Res. 52, 6430-6437. 